\title{
Dechlorinating transformation of propachlor through nucleophilic substitution by dithionite on the surface of alumina
}

\author{
Chengshuai Liu • Kaimin Shih • Yuanxue Gao • \\ Fangbai Li $\cdot$ Lan Wei
}

Received: 7 January 2012 / Accepted: 15 March 2012 /Published online: 30 March 2012

(C) The Author(s) 2012. This article is published with open access at Springerlink.com

\begin{abstract}
Purpose The aim of this study was to evaluate the roles of aluminum-based minerals, especially their surface Lewis acid sites (LASs), on the transformation and fate of chloroacetanilide herbicide contaminants when nucleophilic reagents are present.

Materials and methods Batch experiments were used to study propachlor transformation processes under different reaction conditions. The surface bonding of aluminas before and after interacting with propachlor and dithionite were characterized by Fourier transform infrared (FTIR) spectra. The LASs on different aluminas, acting as the key role for accelerating the propachlor transformation, were analyzed by pyridine adsorption/FTIR spectroscopic technique.

Results and discussion Rates of dithionite-initiated propachlor dechlorination were increased in the presence of aluminas. Transformation efficiencies of propachlor on different aluminas were found to be as $\gamma-\mathrm{Al}_{2} \mathrm{O}_{3}>\gamma-\mathrm{AlOOH}>\alpha-\mathrm{Al}_{2} \mathrm{O}_{3}$. A higher reaction temperature, higher $\mathrm{pH}$, and higher alumina dosage can further increase the propachlor dechlorination rate.
\end{abstract}

Responsible editor: Jay Gan

Electronic supplementary material The online version of this article (doi:10.1007/s11368-012-0506-0) contains supplementary material, which is available to authorized users.

C. Liu $\cdot$ Y. Gao $\cdot$ F. Li $(\bowtie) \cdot$ L. Wei

Guangdong Key Laboratory of Agricultural Environment Pollution Integrated Control,

Guangdong Institute of Eco-Environmental and Soil Sciences,

Guangzhou 510650, People's Republic of China

e-mail: cefbli@soil.gd.cn

C. Liu $\cdot$ K. Shih $(\square)$

Department of Civil Engineering, The University of Hong Kong,

Pokfulam Road,

Hong Kong, People's Republic of China

e-mail: kshih@hku.hk
The addition of citric acid may block the active sites on alumina and reduce propachlor transformation by dithionite. FTIR and pyridine adsorption/diffuse reflectance Fourier transform infrared spectroscopy indicated that $\mathrm{Al}-\mathrm{S}$ and $\mathrm{Al}-\mathrm{O}$ bonds on the LASs of alumna play a key role in accelerating propachlor transformation.

Conclusions LASs on alumina surfaces can effectively accelerate the propachlor transformation by dithionite. The strong electron accepting ability of LASs gives dithionite a favorable affinity to form surface sulfur compounds, which are stronger reductants and nucleophilic reagents for propachlor dechlorination. The intensities of LASs on alumina surfaces can be used to control the rate of propachlor transformation by dithionite.

Keywords Aluminum oxide - Chloroacetanilide herbicides . Lewis acid site $\cdot$ Nucleophilic reagent $\cdot$ Soil mineral

\section{Introduction}

Chloroacetanilide herbicides are one of important classes of pesticides. They are usually used in agricultural cultivation to prevent the growth of weeds, such as annual grasses and some broadleaf plants (Kumari et al. 2009). Excessive application of chloroacetanilide herbicides has resulted in severe nonpoint contamination in soils. Because of the recognized ecotoxicity of chloroacetanilide pesticides, understanding remediation methods for soils polluted by these compounds is of interest (Cai et al. 2011).

Natural degradation processes for chloroacetanilides, such as photolysis, oxidative degradation, and biotransformation, are usually negligible or substantially slower in subsurface soil due to the lack of sufficient oxygen and light (Osano et al. 2003). Although chloroacetanilides may 
undergo fast transformation by hydrolysis in highly moist soils under very specific conditions, its hydrolysis half-life $\left(t_{1 / 2}\right)$ is usually $>5$ months in darkened, sterile, and buffered soil solutions (Bian et al. 2009). Because of this resistance to degradation, exploiting the reductive transformation of chloroacetanilides through nucleophilic substitution in soil has recently received considerable attention (Lippa et al. 2004). Because of the high reducing potential and strong nucleophilic abilities, the sulfur compounds, such as biosulfate (Bian et al. 2009), thiosulfate (Gan et al. 2002; Cai et al. 2007), and polysulfide (Loch et al. 2002), have been reported to readily dehalogenate organic halogenated pollutants efficiently. Dithionite is a relatively inexpensive sulfur compound which has long been used extensively in industrial applications (de Carvalho and Schwedt 2002). As to environmental cleaning purposes, in recent years, dithionite has been used to treat soils and sediments to enhance pollutant decomposition in soils and groundwater, and dithionite itself was decomposed into environmentally benign compounds (Boparai et al. 2006; Ludwig et al. 2007). However, the reaction pathways of dithionite in soils may be very complex due to the existence of various active components in the subsurface environment. One complexity which merits further investigation is the role of dithionite in assisting other reducing agents, or being assisted by them, during the chloroacetanilide dechlorination process.

Soil minerals, including aluminum oxides, iron oxides, and manganese oxides, etc., are active components in soil and have been shown to be important in many geochemical processes. Reactions at the mineral-water interface are an important topic in a variety of applications ranging from mineral beneficiation to contaminant detergency (Eng et al. 2000). Aluminum is one of the most abundant metallic elements of the Earth's crust $(8.1 \%$ by the weight) (Greenwood and Earnshaw 1997). Except when strongly dissolved into ion forms or concentrated in soils, aluminumbased minerals are usually environmentally benign for subsurface biological and geochemical processes (Banks and Kastin 1989; Dill 2010).

Aluminum (hydro)oxides are common aluminum-based minerals in soil, and their behavior is representative of typical chemical properties of aluminum-based minerals (Goldberg et al. 1994). Alumina surfaces have been found to be more reactive when compared with many other soil minerals, and this reactivity has been widely used for fabricating adsorbents (Al-Abadleh and Grassian 2003; Essington and Anderson 2007; Álvarez et al. 2011; Wang and Shih 2011) and catalysts (Hass et al. 1998; He et al. 2005). Dried aluminas commonly chemisorb at least a monolayer of water when exposed to moisture at ambient conditions, and when the surfaces are hydrated, the top layer of oxide ions will be converted into a filled and square lattice of hydroxyl ions (Goldberg et al. 1994). However, aluminum ions on the edge faces (100 and 110 planes) of alumina may have unsatisfied positive charge, which means the surface $\mathrm{Al}$ sites can act as strong Lewis acid sites (LASs). The solid acid sites on the surface of alumina are extremely active and are the main reason for alumina's wide usage as an adsorbent and catalyst (Kasprzyk-Hordern 2004; Nassar et al. 2011). As a result, aluminum-based minerals may affect the transformation processes of chloroacetanilide herbicides in environment, especially when paired with reactive compounds such as dithionite as a decontamination strategy. Dosing contaminated soils with aluminum minerals and dithionite may be a promising decontamination strategy; however, relatively few studies have focused on the reductive dechlorination of chloroacetanilide herbicides under these conditions.

In this study, we systematically investigated the dechlorinating transformation of chloroacetanilide herbicides by dithionite in the presence of aluminas. Propachlor (2-chloro- $N$-(1-methylethyl)- $N$-phenylacetamide), one of the most widely used chloroacetanilide herbicides in China and with the longest usage history (Hua 2011), was used as the test herbicide. The primary goals of the study were to evaluate the effect of alumina on the transformation efficiency of propachlor by dithionite and to identify the role of alumina in the propachlor transformation mechanism. To achieve these goals, experiments were conducted to first determine the kinetics of propachlor transformation under the influences of dithionite and alumina and then to characterize the alumina surface features to reveal the interfacial reaction mechanisms of propachlor transformation by dithionite on alumina.

\section{Materials and methods}

\subsection{Materials}

Propachlor (99.9 \% purity) was obtained from SigmaAldrich (St. Louis, MO, USA). The phosphate buffer was obtained from Fisher Scientific (Loughborough, UK). Sodium dithionite and other chemicals for the study were of analytical grade and purchased from BDH Chemicals (Poole, UK). Ultrapure water $(18 \mathrm{M} \Omega \mathrm{cm})$ generated from a Milli-Q water purification system was used to prepare the chemical solutions and for the mobile phase of liquid chromatography. All chemicals were used as purchased without further purification.

Three types of alumina materials $\left(\gamma-\mathrm{AlOOH}, \gamma-\mathrm{Al}_{2} \mathrm{O}_{3}\right.$, and $\left.\alpha-\mathrm{Al}_{2} \mathrm{O}_{3}\right)$ were used in this study. The boehmite $(\gamma-\mathrm{AlOOH})$ used in this study was received as PURAL SB powder (Sasol, Lake Charles, LA, USA). The $\gamma-\mathrm{Al}_{2} \mathrm{O}_{3}$ was prepared from the boehmite powder by thermal treatment at $650{ }^{\circ} \mathrm{C}$ for $3 \mathrm{~h}$. The corundum $\left(\alpha-\mathrm{Al}_{2} \mathrm{O}_{3}\right)$ was obtained by further calcining the $\gamma-\mathrm{Al}_{2} \mathrm{O}_{3}$ at $1,500{ }^{\circ} \mathrm{C}$ for $6 \mathrm{~h}$. The crystal structures of these materials were confirmed by 
X-ray diffraction (XRD) analysis. The details of the X-ray diffractometer, data scanning parameters, and the obtained XRD patterns of the alumina materials are available at Online Resource 1 and Fig. S1 of Electronic Supplementary Material.

\subsection{Experimental procedures}

A stock solution of $250 \mathrm{mg} \mathrm{L}^{-1}$ propachlor was prepared by dissolving $250 \mathrm{mg}$ propachlor in $1 \mathrm{~L}$ ultrapure water. Other stock solutions were also prepared with ultrapure water, and all solutions were stored in $4{ }^{\circ} \mathrm{C}$ before experiments. Aqueous solutions of propachlor $\left(10 \mathrm{mg} \mathrm{L}^{-1}\right)$ and dithionite $(5 \mathrm{mM})$ in $20 \mathrm{~mL}$ volumes were prepared in borosilicate glass serum bottles with phosphate buffer $\left(0.02 \mathrm{~mol} \mathrm{~L}^{-1}\right)$ at varying $\mathrm{pH}(4.0,7.0$, and 9.0) and reaction temperatures $\left(25,40\right.$, and $\left.55{ }^{\circ} \mathrm{C}\right)$. After adding the designated doses $\left(1.0,2.0\right.$, or $\left.4.0 \mathrm{~g} \mathrm{~L}^{-1}\right)$ of alumina materials $(\gamma-\mathrm{AlOOH}, \gamma-$ $\mathrm{Al}_{2} \mathrm{O}_{3}$, or $\alpha-\mathrm{Al}_{2} \mathrm{O}_{3}$ ), the bottles were covered with Teflonlined butyl rubber septa and aluminum crimp seals and then placed onto a 150-rpm orbital shaker (LMS Cooled Incubators, Wolf Laboratories Limited, UK). Control samples without alumina added were prepared according to the treatments given above. To study the interaction between dithionite and aluminas, dithionite $(5 \mathrm{mM})$ was added to bottles with the aluminas $\left(2.0 \mathrm{~g} \mathrm{~L}^{-1}\right)$ at $\mathrm{pH} 7.0$ and $25{ }^{\circ} \mathrm{C}$ in the absence of propachlor. At specified intervals, aliquot was collected from each bottle with a syringe and filtered by a $0.22-\mu \mathrm{m}$ polytetrafluoroethylene syringe quickly. Then, the filtrate $(4 \mathrm{~mL})$ was immediately quenched by adding excess methanol $(36 \mathrm{~mL})$ before compositional analyses (Goerke et al. 1971). The alumina samples after reaction were collected, centrifuged at 4,000 rpm for $10 \mathrm{~min}$, freeze-dried for $12 \mathrm{~h}$, and purged by nitrogen gas for Fourier transform infrared spectroscopy (FTIR) analysis.

\subsection{Chromatography analyses of propachlor} and the transformation products

A high-performance liquid chromatography (HPLC) system (Shimadzu, Japan) was used for the quantitative determination of propachlor concentrations during transformation reactions. The HPLC system was equipped with a LC-10A pump, SIL-10A automatic injector, and SPD 10A-UV-vis detector. Propachlor separation was carried out by an Alltima $^{\mathrm{TM}} \mathrm{C} 18$ column $(5 \mu \mathrm{m}$ beads, $250 \times 4.6 \mathrm{~mm}$ I.D. $)$ with a mobile phase of $70 \%$ methanol and $30 \%$ water at a flow rate of $1.0 \mathrm{~mL} \mathrm{~min}{ }^{-1}$. The wavelength used for detecting propachlor was $215 \mathrm{~nm}$. An ion chromatography (IC) system (ICS-90, DIONEX, USA) was used for the determination of chloride concentrations in the reaction solutions. The IC was equipped with a RFICTM IonPac $^{\circledR}$ AG14A-7 $\mu \mathrm{m}$ guard column $(4,50 \mathrm{~mm})$, an AMMS III micromembrane suppressor, an IonPac ${ }^{\circledR}$ AS14A-7 $\mu \mathrm{m}$ analytical column $(4,250 \mathrm{~mm})$, and a DS5 detection stabilizer. The eluent solution containing $8.0 \mathrm{mM} \mathrm{Na}_{2} \mathrm{CO}_{3}$ and $1.0 \mathrm{mM} \mathrm{NaHCO}$ was pumped into the system at a flow rate of $1.0 \mathrm{~mL} \mathrm{~min}^{-1}$. The limits of detection and quantitation were 7 and $24 \mu \mathrm{g} \mathrm{L}^{-1}$, respectively, and the relative standard deviation was within $5 \%$. Concentrations of dithionite were determined by the naphthol yellow $\mathrm{S}$ spectrophotometric method at $502 \mathrm{~nm}$ with a UV-vis spectrophotometer (UV-vis TU-1800, Purkinje General, Beijing, China) (de Carvalho and Schwedt 2002). Liquid chromatography/mass spectrometry (LC/MS) was used for the qualitative determination of the propachlor transformation intermediates, and the analysis was conducted on a Shimadazu HPLC system with an API 3000 mass analyzer with the operational details provided in Online Supplementary Material 3.

\subsection{Infrared spectroscopy analyses of aluminas}

The FTIR spectra of alumina powder samples were recorded with a FTIR spectrometer (Bruker Vector 33, Germany). Sixty-four scans were collected for each measurement in the spectral range of $4,000-400 \mathrm{~cm}^{-1}$ with a resolution of $4 \mathrm{~cm}^{-1}$. Specimens were prepared for FTIR measurement by mixing dried samples with spectroscopic grade $\mathrm{KBr}$ and then compressing the mixtures into pellet form for the measurements. To obtain more information on the acid sites on alumina surfaces, diffuse reflectance infrared Fourier transform spectroscopy (DRIFT) was employed to identify the acid sites, using pyridine as a probe molecule similar to the method reported previously (Liu et al. 2011b). The characterization of DRIFT was performed with a Praying Mantis $^{\text {TM }}$ diffuse reflection accessory (Harrick Scientific Products, Inc., Pleasantville, NY, USA) for a Bruker Vertex-70 Fourier transform infrared spectrometer at room temperature. The DRIFT measurement lasted $2 \mathrm{~min}$ (from loading the sample to recording the spectrum), and the ambient relative humidity was $\sim 30 \%$. The spectra were collected over the range of $1,600-1,300 \mathrm{~cm}^{-1}$ with 64 scans and a resolution of $4 \mathrm{~cm}^{-1}$ using $\mathrm{KBr}$ background. The baseline correction was performed by using the OPUS ${ }^{\mathrm{TM}}$ 6.5 software (Bruker Optik, Ettingen, Germany).

\section{Results}

\subsection{Propachlor transformation by dithionite on aluminas}

The influence of dithionite on propachlor transformation on the three types of alumina materials $\left(\gamma-\mathrm{AlOOH}, \gamma-\mathrm{Al}_{2} \mathrm{O}_{3}\right.$, and $\alpha-\mathrm{Al}_{2} \mathrm{O}_{3}$ ) is shown in Fig. 1. The results with alumina only indicate that the adsorption of propachlor on alumina surfaces is negligible and the propachlor concentrations in 
Fig. 1 Dechlorination of propachlor $\left(10 \mathrm{mg} \mathrm{L}^{-1}\right)$ by $5 \mathrm{mM}$ dithionite and the generation of chlorine ions with three types of alumina materials at $25{ }^{\circ} \mathrm{C}$ and $\mathrm{pH} 7$

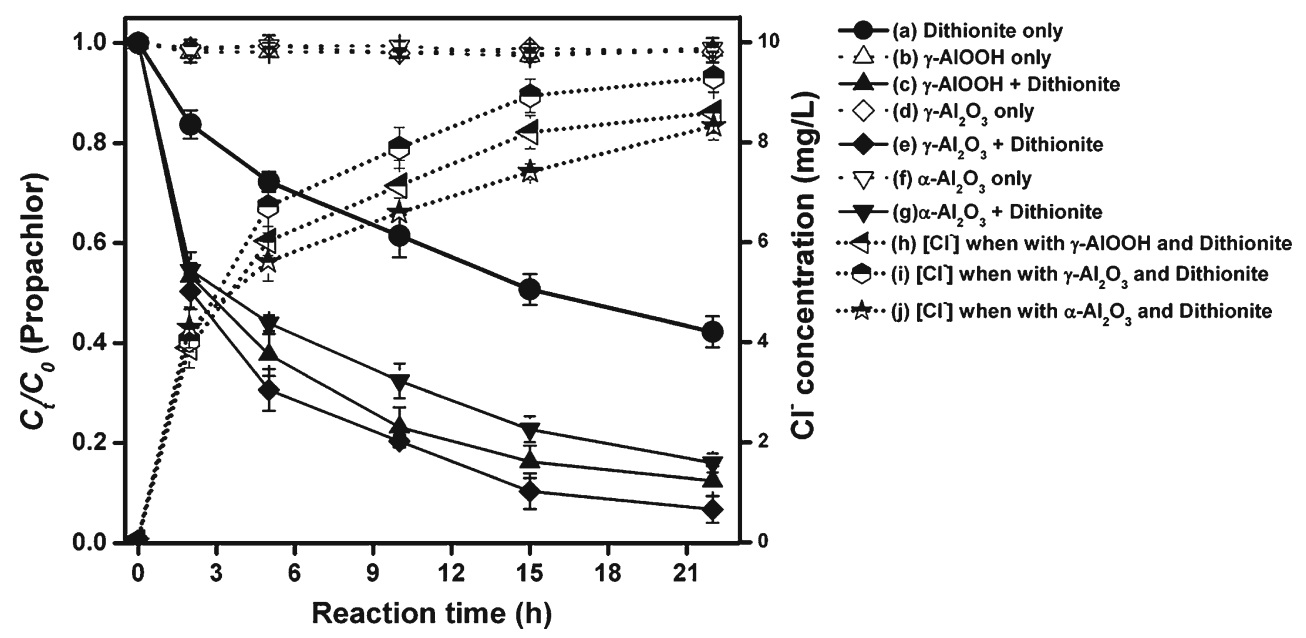

systems without dithionite remained constant throughout the testing period. As expected, as an active reductant and nucleophile reagent (Nzengung et al. 2001), dithionite produced a significant effect on propachlor transformation (see Fig. 1). With $5 \mathrm{mM}$ dithionite, $57.7 \%$ of propachlor (initial concentration $=10 \mathrm{mg} \mathrm{L}^{-1}$ ) was transformed after $22 \mathrm{~h}$ in the homogeneous system (without alumina material). Under heterogeneous reaction conditions, the transformation rates of propachlor by dithionite were increased by the presence of aluminas in the system. The addition of aluminas resulted in propachlor transformation rates of $87.6 \%$ for $\gamma$-AlOOH, $93.3 \%$ for $\gamma-\mathrm{Al}_{2} \mathrm{O}_{3}$, and $83.9 \% \alpha-\mathrm{Al}_{2} \mathrm{O}_{3}$, which enhanced transformation rates by $29.9,35.6$, and $26.4 \%$, respectively, over dithionite alone. The propachlor concentration data can be well-fitted by pseudo-first-order kinetics with rate constant $(k)$ values of $8.86 \times 10^{-2}\left(R^{2}=0.908\right)$ for $\gamma$-AlOOH, $11.6 \times 10^{-2}\left(R^{2}=0.945\right)$ for $\gamma-\mathrm{Al}_{2} \mathrm{O}_{3}$, and $7.47 \times 10^{-2}$ $\left(R^{2}=0.926\right)$ for $\alpha-\mathrm{Al}_{2} \mathrm{O}_{3}$. Compared with propachlor transformation in the system without alumina $\left(k=3.75 \times 10^{-2}\right.$ $\left.\left(R^{2}=0.972\right)\right)$, the order of the increased enhancement effect from the participation of each alumina species goes as $\gamma-\mathrm{Al}_{2} \mathrm{O}_{3}>\gamma-\mathrm{AlOOH}>\alpha-\mathrm{Al}_{2} \mathrm{O}_{3}$. The increase of chloride ions as shown in Fig. 1 indicates the generation of chloride ions during the propachlor transformation reaction. The mass balance of chlorine in the reaction systems during the reaction processes demonstrates the reductive dechlorination mechanism for propachlor transformation.

\subsection{Effects of reaction conditions on propachlor transformation}

Variations in temperature, $\mathrm{pH}$, and alumina doses may strongly affect the transformation of propachlor and therefore were assessed in this study. Experiments observing the influence of these three operational parameters were conducted in the presence of $\gamma$-AlOOH. Propachlor transformation under varying reaction conditions with and without alumina is shown in Fig. 2. Propachlor transformation in the presence of alumina fits a pseudo-first-order kinetic model, presented in insets in Fig. 2. Propachlor transformation occurred faster at higher temperature, especially with alumina. Propachlor transformation rates with $\gamma$-AlOOH present in the system were $64.9 \%$ for $10{ }^{\circ} \mathrm{C}, 87.6 \%$ for $25{ }^{\circ} \mathrm{C}$, and $97.0 \%$ for $40^{\circ} \mathrm{C}$ in $22 \mathrm{~h}$, with the $k$ values of $4.56 \times 10^{-2}$ for $10^{\circ} \mathrm{C}, 8.86 \times 10^{-2}$ for $25^{\circ} \mathrm{C}$, and $19.4 \times 10^{-2} \mathrm{~h}^{-1}$ for $40{ }^{\circ} \mathrm{C}$. At $55^{\circ} \mathrm{C}$, complete conversion of propachlor was achieved in $15 \mathrm{~h}$ with a $k$ value of $26.2 \times 10^{-2} \mathrm{~h}^{-1}$ (see Fig. $2 \mathrm{a}$ ).

Propachlor transformation at varying $\mathrm{pH}$ is shown in Fig. 2b. Transformation by dithionite was favored at higher $\mathrm{pH}$ regardless of the presence of alumina. In the homogeneous reaction system without $\gamma-\mathrm{AlOOH}$, the propachlor transformation rate reached $69 \%$. With $\gamma$-AlOOH present in the system, propachlor transformation rates increased correspondingly under all $\mathrm{pH}$ conditions. With $2.0 \mathrm{~g} \mathrm{~L}^{-1}$ of $\gamma$-AlOOH in the reaction system, after $22 \mathrm{~h}$ the propachlor concentration was reduced by $67.4 \%(k=8.40 \times$ $\left.10^{-2} \mathrm{~h}^{-1}\right)$ at $\mathrm{pH} 4,87.6 \%\left(k=8.86 \times 10^{-2} \mathrm{~h}^{-1}\right)$ at $\mathrm{pH} 7$, and $98.7 \%\left(k=17.9 \times 10^{-2} \mathrm{~h}^{-1}\right)$ at $\mathrm{pH} 9.0$. Furthermore, the increase of alumina dose in the reaction also increased the propachlor transformation rate (see Fig. 2c). Reductions in propachlor concentration were $71.4 \%\left(k=5.40 \times 10^{-2} \mathrm{~h}^{-1}\right)$ at $1.0 \mathrm{~g} \mathrm{~L}^{-1} \gamma$-AlOOH, 87.6\% $\left(k=8.86 \times 10^{-2} \mathrm{~h}^{-1}\right)$ at $2.0 \mathrm{~g} \mathrm{~L}^{-1}$, and $93.8 \%\left(k=11.2 \times 10^{-2} \mathrm{~h}^{-1}\right)$ at $4.0 \mathrm{~g} \mathrm{~L}^{-1}$. These results corroborate the theory that active sites on alumina surfaces play an important role in enhancing propachlor transformation by dithionite, by providing a larger surface area to participate in heterogeneous reactions.

\subsection{Effect of citric acid on propachlor transformation}

Polycarboxylic acids are produced by plants as root exudates and are active components commonly found in soils (Fransson et al. 2004). Polycarboxylic acids likely attack active sites on aluminum oxides, thus may play an important role in propachlor transformation by dithionite on alumina surfaces (Qiu et al. 2010). Citric acid is a typical 


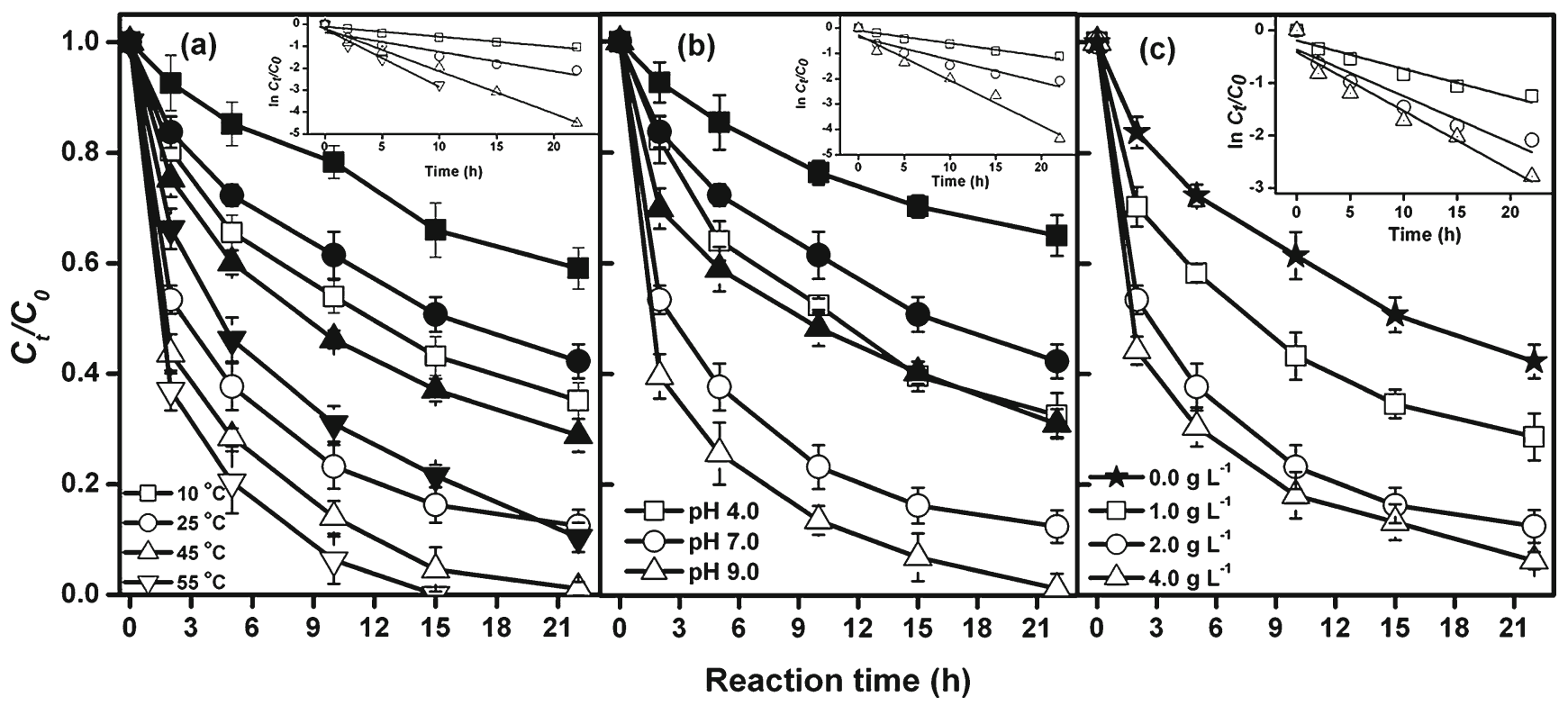

Fig. 2 Propachlor $\left(10 \mathrm{mg} \mathrm{L}^{-1}\right)$ transformation reactions by $5 \mathrm{mM}$ dithionite on $\gamma$-AlOOH under different operational conditions: $a$ the effect of temperature at $\mathrm{pH} 7$ with $2.0 \mathrm{~g} \mathrm{~L}^{-1} \gamma$-AlOOH, $b$ the effect of $\mathrm{pH}$ at $25^{\circ} \mathrm{C}$ with $2.0 \mathrm{~g} \mathrm{~L}^{-1} \gamma-\mathrm{AlOOH}$, and $c$ the effect of alumina dose

polycarboxylic acid, and its influence on propachlor transformation was investigated. We observed that citric acid had a negative effect on propachlor transformation, as shown in Fig. 3. When $1.0 \mathrm{mM}$ citric acid was added to the reaction system (with $5.0 \mathrm{mM}$ dithionite and either $\gamma$-AlOOH, $\gamma$ $\mathrm{Al}_{2} \mathrm{O}_{3}$, or $\alpha-\mathrm{Al}_{2} \mathrm{O}_{3}$ at $2.0 \mathrm{~g} \mathrm{~L}^{-1}$ ), the transformation of propachlor $\left(10 \mathrm{mg} \mathrm{L}^{-1}\right)$ was substantially decreased to $53 \%$ after $22 \mathrm{~h}$, which is even lower than the transformation ratio $(57.3 \%)$ when alumina was not added (see Fig. 3). Compared with the propachlor transformation rates when

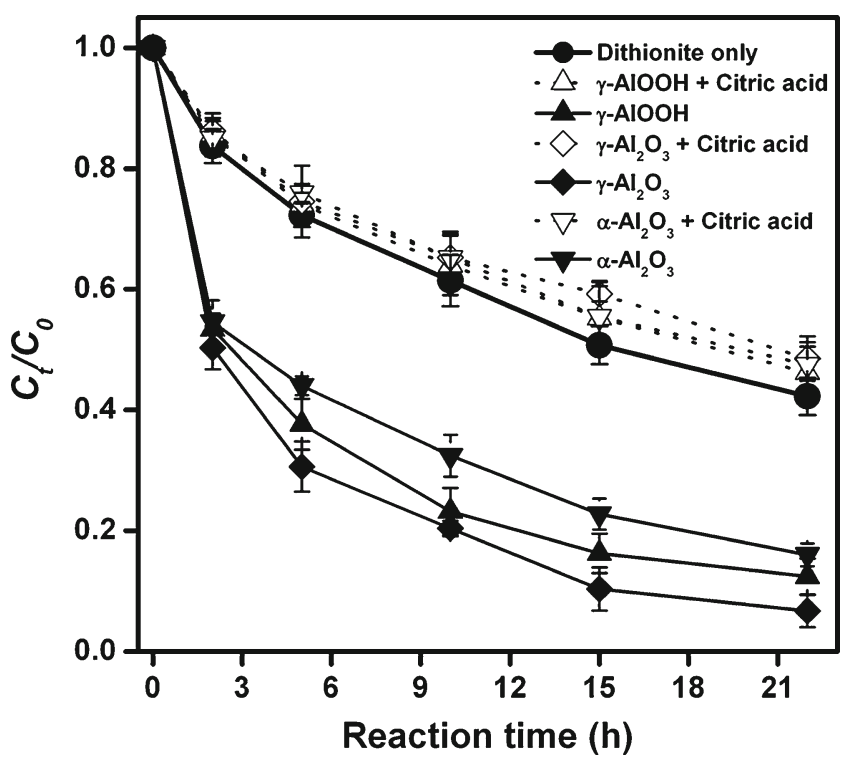

Fig. 3 The influence of citric acid $(1.0 \mathrm{mM})$ on the propachlor $\left(10 \mathrm{mg} \mathrm{L}^{-1}\right)$ dechlorination by $5 \mathrm{mM}$ dithionite on the three alumina materials $\left(2.0 \mathrm{~g} \mathrm{~L}^{-1}\right)$ tested at $25^{\circ} \mathrm{C}$ and $\mathrm{pH} 7$ at $25^{\circ} \mathrm{C}$ and $\mathrm{pH} 7$ (the open symbols are for those with both $\gamma-\mathrm{AlOOH}$ and dithionite in the system, and the solid symbols are for those only with dithionite. The insets are the corresponding open-symbol results fitted by the pseudo-first-order kinetic model)

having alumina and dithionite but not citric acid, the propachlor transformation rates after adding citric acid were largely reduced, even lower than that only with dithionite. This observation may suggest that the role of alumina surface was completely eliminated after the modification by citric acid.

\subsection{Fourier transform infrared spectroscopy}

The FTIR spectra of alumina samples before any reactions, after contact with propachlor, and after participating in the propachlor transformation by dithionite are shown in Fig. 4. For the $\gamma$-AlOOH surface before any reactions (curve $a_{1}$ ), the two bands with wavenumbers 3,404 and $3,089 \mathrm{~cm}^{-1}$ are attributed to $-\mathrm{OH}$ bonds, and the two bands at 2,099 and $1,639 \mathrm{~cm}^{-1}$ are attributed to $\mathrm{H}-\mathrm{O}-\mathrm{H}$ bonds. The band at $1,072 \mathrm{~cm}^{-1}$ corresponds to the $\delta_{s} \mathrm{Al}-\mathrm{O}-\mathrm{H}$ mode of boehmite and the bands at $884,740,621$, and $479 \mathrm{~cm}^{-1}$ are attributed to the Al-O bonds of boehmite ( $\mathrm{Li}$ et al. 2008). For the $\gamma-\mathrm{Al}_{2} \mathrm{O}_{3}$ surface before any reaction (curve $\mathrm{b}_{1}$ ), some $-\mathrm{OH}$ and $\mathrm{H}-\mathrm{O}-\mathrm{H}$ bands could still be identified in the spectra but had lower transmittance intensities. The bands for $-\mathrm{OH}$ and $\mathrm{H}-\mathrm{O}-\mathrm{H}$ bonds were not observed at all for the $\alpha-\mathrm{Al}_{2} \mathrm{O}_{3}$ surface before any reactions (curve $c_{1}$ ). The bands of low wavenumbers of $759,630,652,617,554$, and $465 \mathrm{~cm}^{-1}$ observed in the $\gamma-\mathrm{Al}_{2} \mathrm{O}_{3}$ and $\alpha-\mathrm{Al}_{2} \mathrm{O}_{3}$ samples are attributed to a pseudoboehmite structure (Ren et al. 2004; $\mathrm{Zu}$ et al. 2011). After contact with propachlor, the observed spectra for $\gamma$-AlOOH (curve $\mathrm{a}_{2}$ ) and $\gamma-\mathrm{Al}_{2} \mathrm{O}_{3}$ (curve $\mathrm{b}_{2}$ ) surfaces are nearly identical to their original states before any potential reactions occurred, except a small increase in band 
Fig. 4 FTIR spectra of the alumina samples: $a \gamma$-AlOOH, $b \gamma-\mathrm{Al}_{2} \mathrm{O}_{3}$, and $c \alpha-\mathrm{Al}_{2} \mathrm{O}_{3}$. The curves in each figure include the FTIR spectra of alumina samples: before any potential reactions $\left(a_{1}, b_{1}\right.$, and $\left.c_{1}\right)$, after contacting with propachlor for $10 \mathrm{~h}\left(a_{2}, b_{2}\right.$, and $\left.c_{2}\right)$, and after participating in the reaction of propachlor and dithionite for $10 \mathrm{~h}\left(a_{3}, b_{3}\right.$, and $\left.c_{3}\right)$

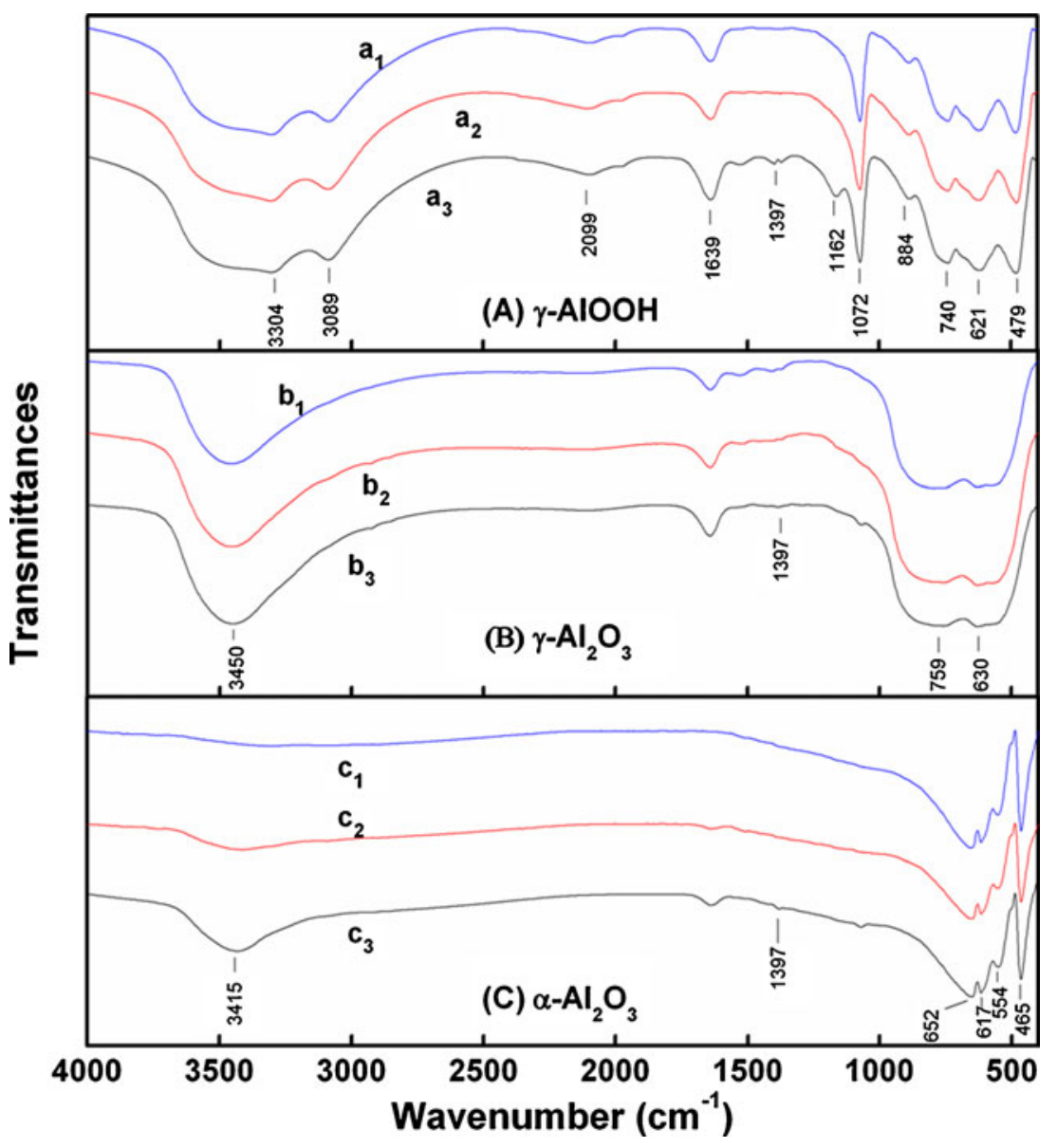

intensities. For $\alpha-\mathrm{Al}_{2} \mathrm{O}_{3}$ (curve $\mathrm{c}_{2}$ ), the bands corresponding to $-\mathrm{OH}$ and $\mathrm{H}-\mathrm{O}-\mathrm{H}$ bonds were found to increase after exposure to water and the propachlor solution. After participating in the propachlor transformation reaction with dithionite for $10 \mathrm{~h}$, new bands were observed in the spectra at 1,397 and $1,162 \mathrm{~cm}^{-1}$ for $\gamma-\mathrm{AlOOH}$ (curve $\mathrm{a}_{3}$ ) and at $1,397 \mathrm{~cm}^{-1}$ for $\gamma-\mathrm{Al}_{2} \mathrm{O}_{3}$ (curve $\mathrm{b}_{3}$ ) and $\alpha-\mathrm{Al}_{2} \mathrm{O}_{3}$ (curve $\mathrm{c}_{3}$ ) (the FTIR spectra between 1,500 and 1,100 wavenumbers are presented in Fig. S2 of Electronic Supplementary Material for clearer identification of these bands). The band at $1,162 \mathrm{~cm}^{-1}$ has been reported to be attributed to the Al-S bond, and the $1,397-\mathrm{cm}^{-1}$ band was identified as the stretching of $\mathrm{Al}-\mathrm{O}$ bonds in aluminum sulfur compounds (Skoglundh et al. 2001; Gracia et al. 2005).

Surface LASs on alumina are one of the most important chemical properties of alumina materials, due to their potential to affect many heterogeneous reactions facilitated by the metal oxide surface. Therefore, the surfaces of the alumina samples before and after participating in the reaction of propachlor transformation by dithionite were further examined by pyridine adsorption/FTIR spectroscopy technique, and the results are shown in Fig. 5. Before reaction, all three alumina materials were found had a $1,450-\mathrm{cm}^{-1}$ band for adsorbed pyridine, and this has been reported as an indication of LASs (Liu and Truitt 1997). For the transmittance intensities of band $1,450 \mathrm{~cm}^{-1}$ in the three aluminas, the band in $\gamma-\mathrm{AlOOH}$ (curve $\mathrm{a}_{1}$ ) is obviously lower than those in the other two aluminas (curve $b_{1}$ and $c_{1}$ ), which possess the similar intensities. After the propachlor transformation by dithionite, the $1,450-\mathrm{cm}^{-1}$ band disappeared in all three alumina species. This result indicates that the LASs on alumina surfaces were occupied and not available for the adsorption of pyridine.

\section{Discussion}

Our study has revealed the role of dithionite, a type of active sulfur compound, in propachlor reductive dechlorination through nucleophilic substitution via the $\mathrm{S}_{\mathrm{N}} 2$ mechanism (Liu et al. 2011a). The presence of alumina was found to accelerate propachlor transformation by dithionite, and such an effect may be attributed to the active surface properties, especially the surface acid sites, of alumina. However, propachlor did not adsorb on $\gamma-\mathrm{AlOOH}, \gamma-\mathrm{Al}_{2} \mathrm{O}_{3}$, or $\alpha-\mathrm{Al}_{2} \mathrm{O}_{3}$ at neutral $\mathrm{pH}$ conditions as shown in Fig. 1. In aqueous solution, the points of zero charge of aluminas vary from about 7 to 10 (Goldberg et al. 1994), and propachlor was either 

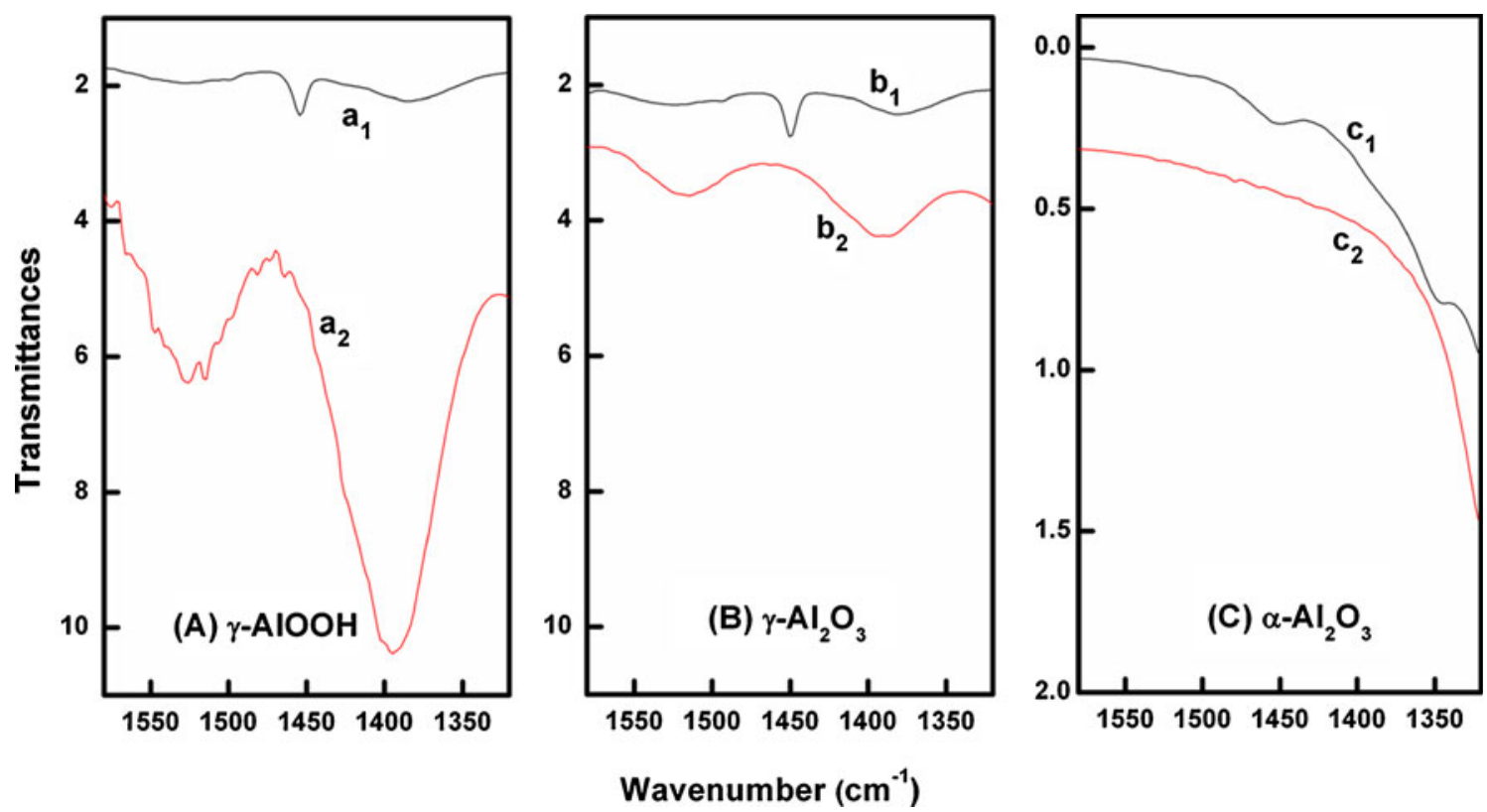

Fig. 5 DRIFT spectra of pyridine adsorption at room temperature on three alumina materials before $\left(a_{1}, b_{1}\right.$, and $\left.c_{1}\right)$ and after $\left(a_{2}, b_{2}\right.$, and $\left.c_{2}\right)$ participating in the reaction of propachlor and dithionite for $10 \mathrm{~h}$

neutral or positively charged in the studied range. Therefore, no electrostatic adsorption occurred and propachlor remained stable in the presence of aluminas. The LASs on aluminas posed no direct effect on propachlor, and the enhanced propachlor transformation is likely due to the modification of the alumina surface by other active reagents.

Anions like dithionite can contact the alumina-water interface by inner- or outer-sphere modes and possess different adsorption behavior from propachlor (Wijnja and Schulthess 2000). As shown in Fig. 6, concentrations of dithionite in the presence of aluminas decreased significantly during the initial reaction period of $5 \mathrm{~h}$, then kept nearly unchanged, with

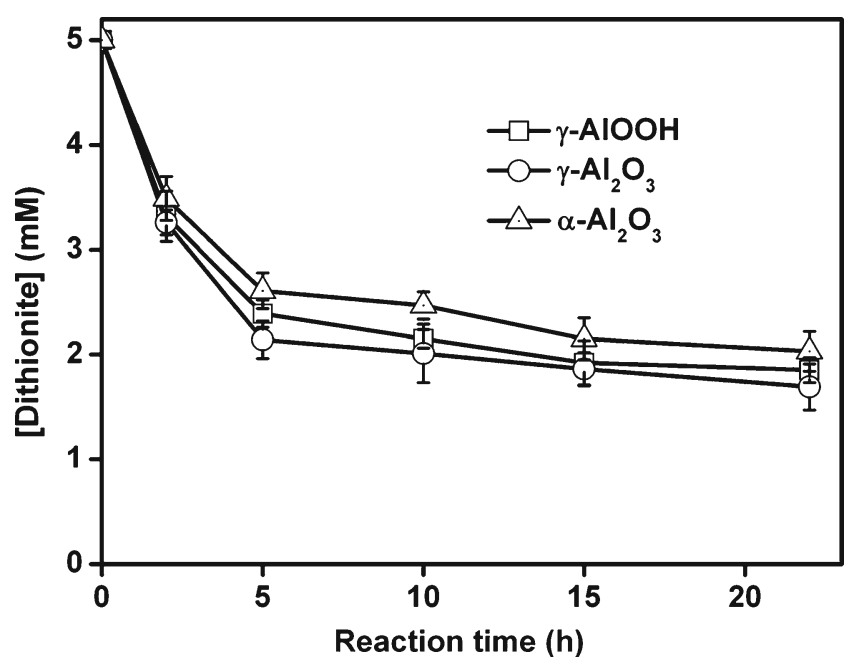

Fig. 6 Changes in dithionite concentrations (initial concentration $5.0 \mathrm{mM})$ when reacted with the three alumina materials $\left(2.0 \mathrm{~g} \mathrm{~L}^{-1}\right)$ without propachlor present in the reaction system $\left(25^{\circ} \mathrm{C}, \mathrm{pH} 7\right)$ aluminas in the order of greatest decrease as $\gamma-\mathrm{Al}_{2} \mathrm{O}_{3}>$ $\gamma-\mathrm{AlOOH}>\alpha-\mathrm{Al}_{2} \mathrm{O}_{3}$. This trend has the same order as that the observed propachlor transformation rates for the three studied aluminas. Inner-sphere surface complexes are rapidly formed as a result of direct chemical bond formation between dithionite and the aluminum ions at the alumina surface (Lewis acid sites). As indicated by our FTIR results, after reaction with dithionite for $10 \mathrm{~h}$, bonds of $\mathrm{Al}-\mathrm{S}$ and $\mathrm{Al}-\mathrm{O}-\mathrm{S}$ were formed on the alumina surface consisting of Al-S species such as $\equiv \mathrm{Al}-$ $\mathrm{OHSO}_{2}{ }^{2-}, \equiv \mathrm{Al}-\mathrm{OSO}_{2}{ }^{2-}, \equiv \mathrm{Al}-\mathrm{SO}_{2}{ }^{-}$, and $\equiv \mathrm{Al}-\mathrm{SO}_{3}{ }^{3-}$ (Gracia et al. 2005), through adsorption reactions and surface groups' protonation. These polar surface species are stronger reductants and nucleophiles due to the enrichment of electrons near sulfur and may explain the higher propachlor transformation rate than that with dithionite alone. Reaction products other than chloride ions generated during the propachlor transformation were determined by LC/MS technique, and two intermediates, propachlor dithionite $\left(\mathrm{C}_{11} \mathrm{H}_{15} \mathrm{NOS}_{2} \mathrm{O}_{4}\right)$ and propachlor ethanesulfonic acid (ESA; $\mathrm{C}_{11} \mathrm{H}_{15} \mathrm{NOSO}_{3}$ ), were clearly identified (chromatograms are presented in Fig. S3 of Electronic Supplementary Material). An intermediate of propachlor transformation with dithionite only (chromatograms are presented as Fig. S4 in Electronic Supplementary Material) (Liu et al. 2011a), hydroxyl propachlor $\left(\mathrm{C}_{11} \mathrm{H}_{15} \mathrm{NO}_{2}\right)$, was not detected. This may be attributed to the stronger reductive and nucleophilic properties of the surface $\mathrm{Al}-\mathrm{S}$ species, which led to the direct formation of propachlor dithionite and ESA through nucleophilic substitution reactions. The dechlorination of propachlor is important for the detoxification of this herbicide (Gan et al. 2002). For example, the toxicity reduction of chloroacetanilide herbicides (i.e., higher lethal concentration 
50) may be explained by the generation of more readily biodegradable metabolites after the chlorine atom was dechlorinated (Cai et al. 2007). Based on the analyses of surface Al-S species and the transformation intermediates, a possible propachlor transformation mechanism by dithionite on alumina surfaces can be deduced (Fig. 7).

The structures and functionalities of aluminas with LASs on the surface have been studied in detail, and the strongest LASs were reported for three-, four-, or five-coordinated $\mathrm{Al}^{3}$ ${ }^{+}$on the surface (Liu and Truitt 1997; Eng et al. 2000; Fionov 2002). Our results indicate the important role of alumina LASs in propachlor transformation with dithionite. After reacting with dithionite, the pyridine peaks in the DRIFT spectra of the three alumina materials were strongly reduced (see Fig. 5), indicating that the LASs were occupied by the dithionite through the formation of surface bonds. The results of pyridine adsorption reflected the strongest transmittance intensity on $\gamma-\mathrm{Al}_{2} \mathrm{O}_{3}$, then $\gamma-\mathrm{AlOOH}$, and finally the weakest on $\alpha-\mathrm{Al}_{2} \mathrm{O}_{3}$, and this is consistent with the order of propachlor transformation rates on the three alumina materials (see Fig. 1). Carboxylic acids have strong affinity toward LASs, owing to their $-\mathrm{COOH}$ groups, and the adsorption of this functional group is usually very strong on alumina (Nassar et al. 2011). The coexistence of citric acid and dithionite showed a much stronger affinity of LASs toward citric acid and resulted in the inhibition of dithionite affinity to the aluminas, consequently suppressing the propachlor transformation as shown in Fig. 3.

Higher doses of alumina materials in the same reaction systems can provide a higher density of LASs for dithionite affinity and thus lead to increased propachlor transformation (see Fig. 2c). The reaction $\mathrm{pH}$ is also important for dithionite reactions on alumina surfaces. Under acidic conditions,
$\mathrm{H}_{2} \mathrm{~S}_{2} \mathrm{O}_{4}$ and/or $\mathrm{HS}_{2} \mathrm{O}_{4}{ }^{-}$are the predominant species, but at higher $\mathrm{pH}$ more $\mathrm{HS}_{2} \mathrm{O}_{4}{ }^{-}$ions may be deprotonated into $\mathrm{S}_{2} \mathrm{O}_{4}{ }^{2-}$ which leads to an increased affinity toward the positively charged alumina surface (Boparai et al. 2006). Consequently, more $\mathrm{Al}-\mathrm{S}$ and $\mathrm{Al}-\mathrm{O}$ bonds may be formed on the alumina surfaces to accelerate the propachlor transformation. Adsorbates are usually easier to form into the octahedral or tetrahedral position to form $\mathrm{Al}-\mathrm{S}$ and $\mathrm{Al}-\mathrm{O}$ bonds at higher temperatures (Daniell et al. 2001). And also, higher reaction temperatures can induce the excitation of bonds in propachlor to be easier attacked through nucleophilic substitution reaction (Liu et al. 2011a). Therefore, higher propachlor transformation rates would be obtained at elevated reaction temperatures.

\section{Conclusions}

In conclusion, the results of this study show the importance of alumina surfaces in controlling the transformation and fate of propachlor in soils. The LASs on alumina surface have a strong electron accepting capability and can provide active sites for dithionite to form surface species with Al-S and $\mathrm{Al}-\mathrm{O}$ bonds to enhance propachlor transformation. Among the three alumina materials tested in this study, the ability of accelerating propachlor transformation goes as $\gamma-\mathrm{Al}_{2} \mathrm{O}_{3}>\gamma-\mathrm{AlOOH}>\alpha-\mathrm{Al}_{2} \mathrm{O}_{3}$, due to their different LAS densities on the surface. The presence of citric acid, which was more dominant in occupying alumina LASs, reduced affinity of dithionite to LASs and thus decreased propachlor transformation. Reaction conditions, such as a higher temperature, basic $\mathrm{pH}$, and a larger alumina surface area, were all observed as beneficial factors to achieve a higher propachlor transformation rate.

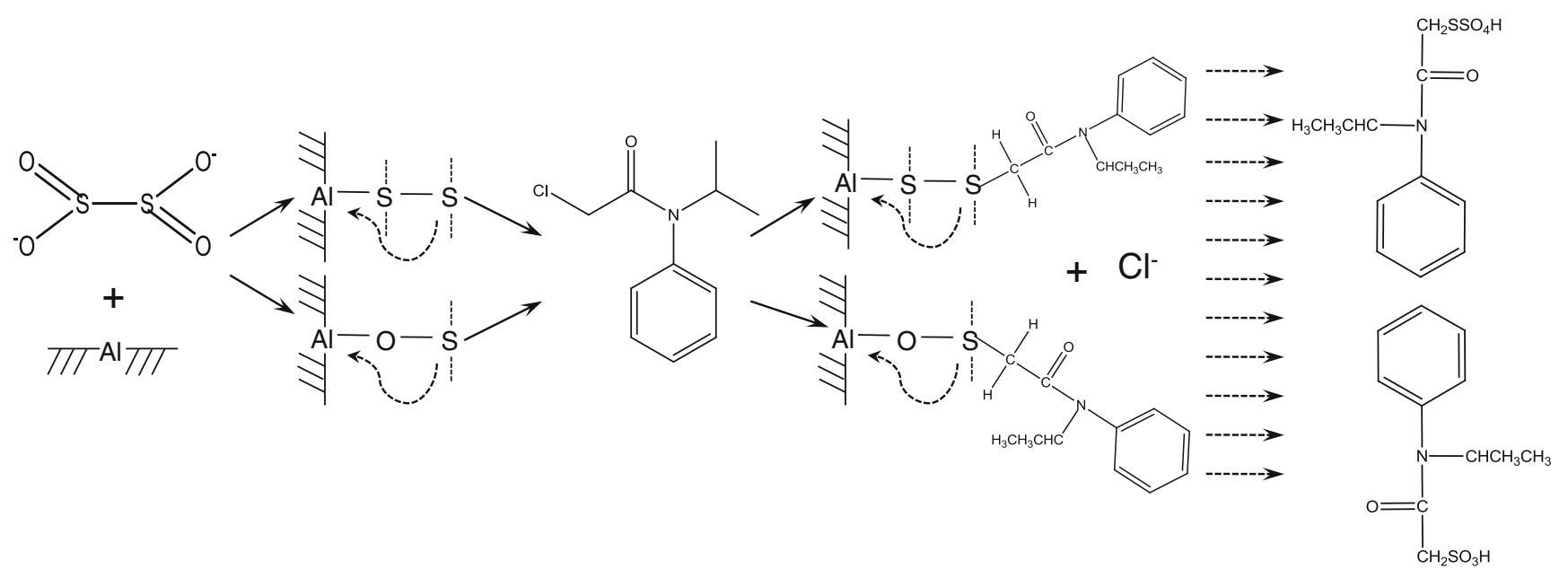

Fig. 7 Schematic diagram of the potential propachlor dechlorination process with dithionite on an alumina surface 
Acknowledgments This study was funded by the National Natural Science Foundation of China (40801086 and 41171364), the Research Grants Council of Hong Kong and its General Research Fund Scheme (HKU 716809E), and the International Foundation for Science (AC/19668). We are thankful to Dr. Dong Liu and Dr. Jianxi Zhu in Guangzhou Institute of Geochemistry, CAS, for their help in DRIFT study. Dr. C. S. Liu thanks The University of Hong Kong for the Postdoctoral Fellowship.

Open Access This article is distributed under the terms of the Creative Commons Attribution License which permits any use, distribution, and reproduction in any medium, provided the original author(s) and the source are credited.

\section{References}

Al-Abadleh HA, Grassian VH (2003) Oxide surfaces as environmental interfaces. Surf Sci Rep 52:63-161

Álvarez E, Fernández-Sanjurjo M, Otero XL, Macías F (2011) Aluminum speciation in the bulk and rhizospheric soil solution of the species colonizing an abandoned copper mine in Galicia (NW Spain). J Soils Sediments 11:221-230

Banks WA, Kastin AJ (1989) Aluminum-induced neurotoxicity: alterations in membrane function at the blood-brain barrier. Neurosci Biobehav Rev 13:47-53

Bian H, Chen J, Cai X, Liu P, Wang Y, Huang L, Qiao X, Hao C (2009) Dechlorination of chloroacetanilide herbicides by plant growth regulator sodium bisulfite. Water Res 43:35663574

Boparai HK, Shea PJ, Comfort SD, Snow DD (2006) Dechlorinating chloroacetanilide herbicides by dithionite-treated aquifer sediment and surface soil. Environ Sci Technol 40:30433049

Cai X, Sheng G, Liu W (2007) Degradation and detoxification of acetochlor in soils treated by organic and thiosulfate amendments. Chemosphere 66:286-292

Cai X, Niu L, Zhang Y, Lang X, Yu Y, Chen J (2011) Discriminating multiple impacts of biogas residues amendment in selectively decontaminating chloroacetanilide herbicides. J Agric Food Chem 59:11177-11185

Daniell W, Topsøe NY, Knözinger H (2001) An FTIR study of the surface acidity of USY zeolites: Comparison of $\mathrm{CO}, \mathrm{CD}_{3} \mathrm{CN}$, and $\mathrm{C}_{5} \mathrm{H}_{5} \mathrm{~N}$ probe molecules. Langmuir 17:6233-6239

de Carvalho LM, Schwedt G (2002) Spectrophotometric determination of dithionite in household commercial formulations using naphthol yellow S. Microchim Acta 138:83-87

Dill HG (2010) The "chessboard" classification scheme of mineral deposits: mineralogy and geology from aluminum to zirconium. Earth-Sci Rev 100:1-420

Eng PJ, Trainor TP, Brown GE Jr, Waychunas GA, Newville M, Sutton SR, Rivers ML (2000) Structure of the hydrated $\alpha-\mathrm{Al}_{2} \mathrm{O}_{3}(0001)$ surface. Science 288:1029-1033

Essington ME, Anderson RM (2007) Competitive adsorption of 2-ketogluconate and inorganic ligands onto gibbsite and kaolinite. Soil Sci Soc Am J 72:595-604

Fionov AV (2002) Lewis acid properties of alumina based catalysis: study by paramagnetic complexes of probe molecules. Surf Sci 507-510:74-81

Fransson AM, Vinogradoff S, Godbold DL, van Hees PAW, Jones DL (2004) Aluminum complexation suppresses citrate uptake by acid forest soil microorganisms. Soil Biol Biochem $36: 353-357$
Gan JY, Wang QQ, Yates SR, Koskinen WC, Jury WA (2002) Dechlorination of chloroacetanilide herbicides by thiosulfate salts. Proc Natl Acad Sci USA 99:5189-5194

Goerke J, de Gier J, Bonsen PPM (1971) Silica gel stimulates the hydrolysis of lecithin by phospholiphase A. Biochim Biophys Acta 248:245-253

Goldberg S, Davis JA, Hem JD (1994) Chapter 7: the surface chemistry of aluminum oxides and hydroxides. In: Sposito G (ed) The environmental chemistry of aluminum, 2nd edn. CRC, Boca Raton, pp 271-331

Gracia FJ, Guerrero S, Wolf EE, Miller JT, Kropf AJ (2005) Kinetics, operand FTIR, and controlled atmosphere EXAFS study of the effect of sulfur on Pt-supported catalysis during CO oxidation. J Catal 233:372-387

Greenwood N, Earnshaw A (1997) Chemistry of the elements, 2nd edn. Butterworth-Heinemann, Oxford, p 217. ISBN 0080379419

Hass KC, Schneider WF, Curioni A, Andreoni W (1998) The chemistry of water on alumina surfaces: reaction dynamics from first principles. Science 282:265-268

He H, Liu J, Mu Y, Yu Y, Chen M (2005) Heterogeneous oxidation of carbonyl sulfide on atmospheric particles and alumina. Environ Sci Technol 39:9637-9642

Hua NZ (2011) Amide herbicides formation and their progress of R \& D. Modern Agrochemicals 10:8-15 (in Chinese)

Kasprzyk-Hordern B (2004) Chemistry of alumina, reactions in aqueous solution and its application in water treatment. Adv Colloid Interf 110:19-48

Kumari N, Narayan OP, Rai LC (2009) Understanding butachlor toxicity in Aulosira fertilissima using physiological, biochemical and proteomic approaches. Chemosphere 77:1501-1507

Li DY, Lin YS, Li YC, Shieh DL, Lin JL (2008) Synthesis of mesoporous pseudoboehmite and alumina template with 1-hexadecyl2,3,-dimethyl-imidazolium chloride. Micropor Mesopor Mat 108:276-282

Lippa KA, Demel S, Lau IH, Roberts AL (2004) Kinetics and mechanism of the nucleophilic displacement reactions of chloroacetanilide herbicides: investigation of $\alpha$-substituent effects. J Agric Food Chem 52:3010-3021

Liu X, Truitt RE (1997) DRIFT-IR studies of the surface of the $\gamma$-A12O3. J Am Chem Soc 119:9856-9860

Liu CS, Shih K, Wei L, Wang F, Li FB (2011a) Kinetics and mechanism of propachlor reductive transformation through nucleophilic substitution by dithionite. Chemosphere 85:1438-1 443

Liu D, Yuan P, Liu H, Cai J, Qin Z, Tan D, Zhou Q, He H, Zhu J (2011b) Influence of heating on the solid acidity of montmorillonite: a combined study by DRIFT and Hammett indicators. Appl Clay Sci 52:358-363

Loch AR, Lippa KA, Carlson DL, Chin YP, Traina SJ, Roberts AL (2002) Nucleophilic aliphatic substitution reactions of propachlor, alachlor, and metolachlor with bisulfide (HS $\left.{ }^{-}\right)$and polysulfide $\left(\mathrm{S}_{\mathrm{n}}{ }^{2-}\right)$. Environ Sci Technol 36:4065-4073

Ludwig RD, Su C, Lee TR, Wilkin RT, Acree SD, Ross RR, Keeley A (2007) In situ chemical reduction of $\mathrm{Cr}(\mathrm{VI})$ in groundwater using a combination of ferrous sulfate and sodium dithionite: a field investigation. Environ Sci Technol 41:5299-5305

Nassar NN, Hassan A, Pereira-Almao P (2011) Effect of surface acidity and basicity of aluminas on asphaltene adsorption and oxidation. J Colloid Interface Sci 360:233-238

Nzengung VA, Castillo RM, Gates WP, Mills GL (2001) Abiotic transformation of perchloroethylene in homogeneous dithionite solution and in suspensions of dithionite-treated clay minerals. Environ Sci Technol 35:2244-2251

Osano O, Nzyuko D, Tole M, Admiraal W (2003) The fate of chloroacetanilide herbicides and their degradation products in the Nzoia Basin, Kenya. Ambio 32:424-427 
Qiu R, Zou Z, Zhao Z, Zhang W, Zhang T, Dong H, Wei X (2010) Removal of trace and major metals by soil washing with $\mathrm{Na}_{2}$ EDTA and oxalate. J Soils Sediments 10:45-53

Ren TZ, Yuan ZY, Su BL (2004) Microwave-assisted preparation of hierarchical mesoporous-macroporous boehmite $\mathrm{AlOOH}$ and $\gamma-\mathrm{Al}_{2} \mathrm{O}_{3}$. Langmuir 20:1531-1534

Skoglundh M, Ljungqvist A, Petersson M, Fridell E, Cruise N, Augustsson O, Jobson E (2001) $\mathrm{SO}_{2}$ promoted oxidation of ethyl acetate, ethanol and propane. Appl Catal B-Environ 30:315-328
Wang F, Shih K (2011) Adsorption of perfluorooctanesulfonate (PFOS) and perfluorooctanoate (PFOA) on alumina: influence of solution $\mathrm{pH}$ and cations. Water Res 45:2925-2930

Wijnja H, Schulthess CP (2000) Interaction of carbonate and organic anions with sulfate and selenate adsorption on an aluminum oxide. Soil Sci Soc Am J 64:898-908

Zu G, Shun J, Wei X, Ni X, Zhang Z, Wang J, Liu G (2011) Preparation and characterization of monolithic alumina aerogels. J NonCryst Solids 357:2903-2906 